\title{
TEKNOLOGI DIGITAL SENSOR WARNA UNTUK MENGUKUR TINGKAT FERMENTASI KAKAO (ULASAN)
}

\author{
Measurement of Cocoa Bean Fermentation Degree \\ with Digital Colour Sensor Technology (Review)
}

\author{
Nurhayati ${ }^{1}$, Ratri Retno Utami ${ }^{2}$, dan Yusdianto ${ }^{3}$ \\ ${ }^{1}$ Fakultas Pertanian, Universitas Muhammadiyah Mataram \\ JI. KH. Ahmad Dahlan, Pagesangan, Mataram, Nusa Tenggara Barat 83115 \\ ${ }^{2}$ Balai Besar Industri Hasil Perkebunan \\ Jl. Prof. Abdurahman Basalamah No. 28 Makassar, Sulawesi Selatan 90231 \\ ${ }^{3}$ Politeknik Akademi Teknologi Industri \\ Jl. Sunu No.220, Suangga, Kec. Tallo, Kota Makassar, Sulawesi Selatan 90211 \\ e-mail: ratri.retno.u@gmail.com
}

\begin{abstract}
SNI 2323-2008 had been set up for cocoa bean quality improvement. Cocoa bean improvement can be achieved with fermentation process. Cocoa bean fermented showed mostly brown color, meanwhile the under-fermented beans show purple colour. Cut test had been done to determine the fermentation degree, this test is qualitative method by visually comparing cut beans color. This method is subjective and gives dispute among traders and farmers. This problem can be solved with digital technology-based innovations using colour sensor. This technology used to know the fermentation degree objectively, effectively and efficiently. This review aims to find the potential of digital color sensor technology that useful to determine the full fermentation degree of cocoa.
\end{abstract}

Keywords: cocoa beans, fermentation, colour sensor, digital technology, cut test

Abstrak: SNI Biji Kakao Nomor 2323-2008 telah diberlakukan untuk meningkatkan kualitas biji kakao. Tahap pengolahan untuk meningkatkan kualitas kakao adalah fermentasi. Fermentasi sempurna ditunjukkan dengan warna coklat dominan, sedangkan fermentasi tidak sempurna ditunjukkan dengan warna ungu. Tingkat fermentasi dapat diketahui melalui metode uji belah, dimana uji ini bersifat kualitatif dengan membandingkan warna keping biji secara visual. Pengujian ini bersifat subyektif yang dapat menyebabkan perbedaan pendapat kualitas biji kakao antara petani dan pedagang. Permasalahan penentuan tingkat fermentasi ini dapat diatasi dengan melakukan inovasi berbasis teknologi digital menggunakan sensor warna. Teknologi ini berguna untuk mengetahui tingkat fermentasi secara obyektif, efektif dan efisien. Ulasan ini bertujuan untuk mengetahui potensi teknologi digital sensor warna sehingga bermanfaat untuk menentukan tingkat fermentasi sempurna dari kakao.

Kata kunci: biji kakao, fermentasi, sensor warna, teknologi digital, uji belah

\section{PENDAHULUAN}

Kakao merupakan salah satu komoditi ekspor non migas yang berperan penting sebagai sumber devisa negara setelah sawit dan karet. Komoditas kakao telah menjadi salah satu komoditas andalan sebagai pendorong perekonomian nasional. Kakao termasuk dalam komoditas strategis unggulan nasional yang difokuskan sejak tahun 2008 sebagai komoditi ekspor unggulan perkebunan (Ditjenbun, 2011). Kemajuan sektor industri menjadikan biji kakao selain dimanfaatkan sebagai bahan baku makanan dan minuman juga sebagai bahan kosmetika, farmasi, kesehatan, dan kecantikan. Dalam perkembangannya, kakao memiliki prospek yang cukup cerah sebab permintaan di dalam negeri juga semakin kuat dengan berkembangnya sektor agroindustri.

Produksi rata-rata perkebunan kakao di Indonesia saat ini masih rendah yaitu $775 \mathrm{~kg} / \mathrm{ha} /$ tahun, jika dibandingkan dengan rata-rata potensi produksi klon unggul sekitar $2000 \mathrm{~kg} / \mathrm{ha}$ /tahun (Ditjenbun, 2016). Berdasarkan data tersebut, program perluasan areal, replanting, rehabilitasi, atau sulaman sebaiknya menggunakan klon unggul yang telah tersedia (Langsa, 2008). Upaya peningkatan produksi kakao 
terus dilakukan oleh pemerintah dengan merealisasikan perluasan areal kakao rakyat. Indonesia berhasil menempatkan diri sebagai produsen kakao terbesar ketiga setelah Pantai Gading dan Ghana pada tahun 2014 dengan produksi sebesar 325 ribu ton dan pada tahun 2015 dengan produksi sebesar 320 ribu ton (ICCO, 2018).

Biji kakao Indonesia yang dihasilkan perkebunan rakyat pada umumnya masih memiliki mutu yang rendah. Rendahnya kualitas biji kakao Indonesia disebabkan karena biji kakao tidak difermentasi (Elisabeth dan Rubiyo, 2006). Umumnya fermentasi yang dilakukan oleh petani tidak memadai, sehingga menyebabkan kadar biji tak terfermentasi cukup tinggi dan menjadi biji dengan mutu terendah (Wahyudi dan Misnawi, 2007). Hal ini juga yang menyebabkan pemasaran biji kakao Indonesia di dunia mengalami hambatan. Produk kakao yang diekspor sebagian besar tidak difermentasi sehingga melemahkan posisi penawaran di mata konsumen dunia (Purba, 2009). Pasar biji kakao internasional menginginkan biji kakao yang telah difermentasi (Kholis, 2009). Biji kakao fermentasi memiliki kualitas dan harga yang lebih baik dari pada biji kakao yang tidak difermentasi. Proses fermentasi biji kakao menjadi sangat penting untuk dilakukan karena menjadi penentu kualitas dan harga biji kakao. Peningkatan kualitas kakao perlu dilakukan yaitu dengan memperbaiki proses fermentasi sehingga diperoleh biji kakao dengan fermentasi sempurna.

Fermentasi digunakan untuk melepaskan pulp dari biji kakao, mencegah pertumbuhan mikroba, memperbaiki kenampakan dan mempermudah pengolahan. Tujuan utama fermentasi adalah mendapatkan biji kakao yang memiliki calon (prekursor) aroma dan cita rasa (flavor) khas cokelat (Yusianto et al., 2008). Fermentasi menyebabkan kematian biji sehingga perubahan-perubahan di dalam biji akan mudah terjadi, seperti warna keping biji dan pembentukan prekursor flavor (Afoakwa et al., 2008; Galvez et al.,
2007). Praktek fermentasi yang tidak tepat akan menghasilkan kerusakan cita rasa biji kakao yang tidak dapat diperbaiki melalui pengolahan selanjutnya. Biji kakao tanpa fermentasi tidak menghasilkan aroma khas cokelat dan memiliki rasa sepat dan pahit yang berlebihan (Misnawi, 2005).

Proses fermentasi dimulai di bagian pulp yang menyelimuti biji, pulp mengandung gula yang tinggi dimana gula ini diubah oleh yeast menjadi etanol. Etanol diubah oleh bakteri asam asetat dan bakteri asam laktat menjadi asam asetat serta asam laktat. Etanol dan asam ini mendifusi kulit biji dan menyebabkan kematian biji. Aktivitas mikroba ini menghasilkan panas yang juga menyebabkan kematian biji. Setelah kematian biji, enzim bereaksi dengan substrat dan membentuk gula serta asam yang merupakan prekursor rasa. Enzim berperan aktif dalam mengurangi rasa sepat, menghilangkan pigmen ungu, membentuk warna cokelat serta membentuk prekursor aroma dan rasa khas cokelat (Hansen et al., 1998; Thompson et al., 2001). Prekursor flavor juga dibentuk oleh reaksi antara sukrosa dan protein (Beckett, 2009). Pembentukan prekursor flavor cokelat dipengaruhi oleh sifat fisik biji kakao. Biji kakao dengan ukuran besar membutuhkan waktu fermentasi lebih lama daripada biji kakao yang lebih kecil. Biji kakao dengan warna ungu lebih gelap membutuhkan waktu yang lebih lama daripada biji cerah (Yusianto et al., 1997). Warna ungu biji berhubungan dengan kandungan zat warna violet dalam biji. Biji kakao dengan jumlah zat warna violet lebih banyak akan memerlukan waktu fermentasi yang lebih lama, namun belum diketahui dengan pasti seberapa jauh pengaruh zat warna violet terhadap pemilihan waktu fermentasi (Haryadi dan Supriyanto, 1991). Protein dan peptida akan bereaksi dengan polifenol untuk menghasilkan warna cokelat. Fermentasi biji kakao akan mengakibatkan perubahan fisik, kimiawi, dan biologi di dalam biji kakao seperti yang disajikan pada Tabel 1 . 
Tabel 1. Mekanisme Perubahan yang Terjadi Selama Fermentasi Kakao

\begin{tabular}{|c|c|c|c|c|c|c|}
\hline Tahap & Bakteri & Waktu & Kondisi & Temperatur & Proses & Perubahan yang terjadi \\
\hline I & Yeast & 24-36 jam & Anaerobic & $\begin{array}{l}27-42^{\circ} \mathrm{C} \\
\mathrm{pH}<4\end{array}$ & $\begin{array}{l}\text { Gula diubah } \\
\text { menjadi alkohol }\end{array}$ & $\begin{array}{l}\text { Kematian biji terjadi } \\
\text { pada hari kedua yang } \\
\text { disebabkan karena asam } \\
\text { asetat dan alkohol }\end{array}$ \\
\hline II & $\begin{array}{l}\text { Bakteri } \\
\text { a s a m } \\
\text { laktat }\end{array}$ & 48-96 jam & Aerobic & & $\begin{array}{l}\text { Gula dan asam } \\
\text { organik diubah } \\
\text { menjadi asam } \\
\text { laktat }\end{array}$ & $\begin{array}{l}\text { Protein diuraikan } \\
\text { oleh enzim menjadi } \\
\text { polipeptida dan asam } \\
\text { amino. Keduanya sebagai } \\
\text { prekursor flavor cokelat }\end{array}$ \\
\hline III & $\begin{array}{l}\text { Bakteri } \\
\text { a s a m } \\
\text { asetat }\end{array}$ & 96-120 jam & Aerobic & $50^{\circ} \mathrm{C}$ & $\begin{array}{l}\text { Alkohol diubah } \\
\text { menjadi asam } \\
\text { asetat }\end{array}$ & $\begin{array}{l}\text { Senyawa protein dan } \\
\text { polifenol dioksidasi, } \\
\text { keduanya mengurangi } \\
\text { rasa sepat }\end{array}$ \\
\hline
\end{tabular}

Sumber : Mulato et al., 2008; Beckett, 2009

Asam asetat yang semula di permukaan biji merembes lewat kulit biji dan masuk ke jaringan daging biji. Kombinasi suasana asam dan panas di dalam biji menyebabkan kemampuan germinasi biji menjadi hilang dan biji menjadi mati (Mulato, 2008). Secara skematis pembentukan asam asetat dan asam laktat disajikan Gambar 1.

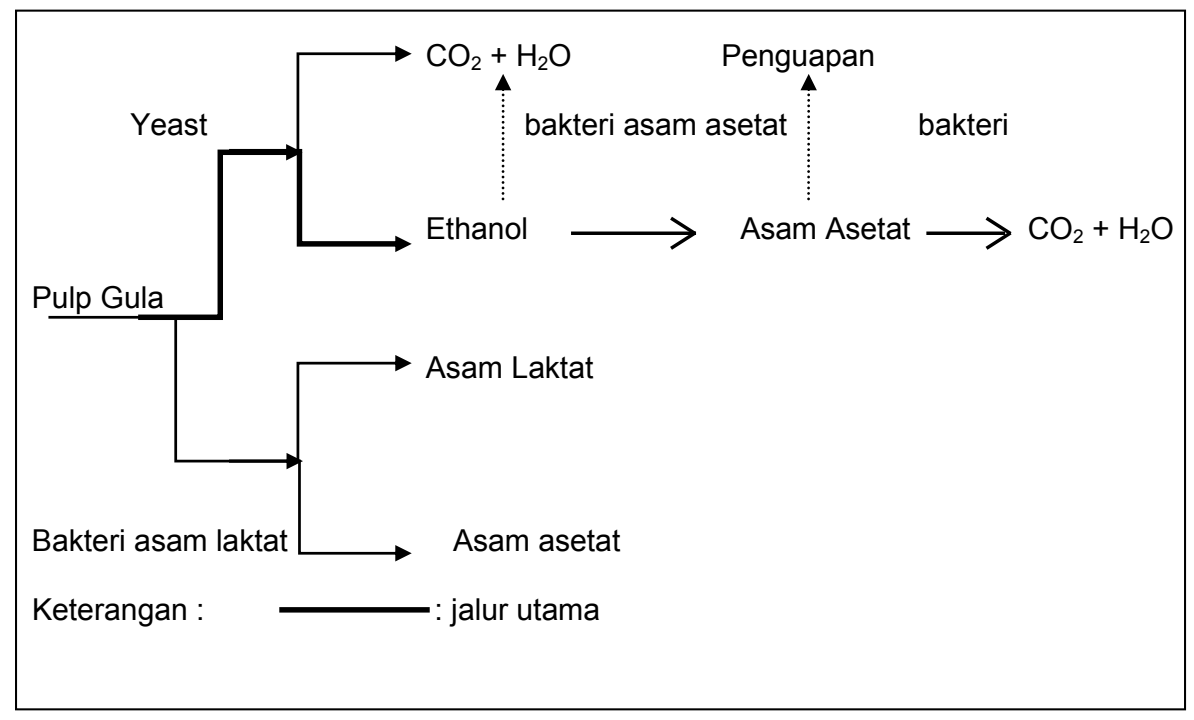

Gambar 1. Pembentukan Asam Asetat dan Asam Laktat dalam Fermentasi (Chong dalam Sulistyowati, 1988).

\section{Penentuan Akhir Fermentasi}

Penentuan akhir fermentasi dapat dilakukan dengan pengamatan suhu, warna, bau, dan kenampakan internal. Warna keping biji kakao dijadikan sebagai penentu akhir fermentasi berdasarkan SNI 2323-2008. Biji kakao sebelum fermentasi berwarna putih kekuningan dan berbau asam. Biji kakao yang terfermentasi berwarna merah kecoklatan dan kotiledon menjadi lebih cerah pada bagian tengah dengan lingkar warna cokelat di bagian pinggir. Biji dengan kondisi seperti ini telah terfermentasi dan siap dikeringkan. Fermentasi yang berlangsung lebih dari 5 hari akan menyebabkan biji berwarna agak 
hitam dan tercium bau amonia, yang berarti bahwa proses fermentasi berlebih (Anonim, 2013). Perubahan warna diakibatkan oleh adanya perubahan kompleks polifenol selama proses fermentasi. Pembentukan warna yang terjadi selama proses fermentasi bersamaan dengan pembentukan prekursor flavor, sehingga warna biji kakao seringkali digunakan sebagai penduga potensi flavor (Camu et al., 2008). Perubahan tersebut tidak akan terjadi jika biji kakao tidak difermentasi.

Penentuan akhir fermentasi dengan pengamatan perubahan warna pada keping bijikakao dilakukan dengan mengukur indeks fermentasi dan uji belah. Pengukuran indeks fermentasi dilakukan dengan menggunakan spektrofotometer, sedangkan uji belah dilakukan secara visual subyektif dan alat semi mekanis. Indeks fermentasi adalah perbandingan absorbansi pada panjang gelombang $460 \mathrm{~nm}$ (flavonoid kompleks) dan $530 \mathrm{~nm}$ (anthocyanin) yang merupakan indikator terjadinya fermentasi sempurna dimana jika terfermentasi sempurna diperoleh angka indeks fermentasi 1 atau lebih (Gourieva, Tserevinov dalam Misnawi, 2005).
Uji belah dilakukan dengan membelah biji kakao membujur di bagian tengah dan dilihat warna serta lekukan rongganya. Tingkat fermentasi berdasarkan warna biji dapat digolongkan menjadi fermentasi berlebihan (biji coklat gelap, bau tidak enak), fermentasi sempurna (biji berwarna coklat dominan), tidak terfermentasi (biji berwarna seperti batu tilis/slaty), biji berwarna ungu sebagian, dan coklat sebagian, serta biji berwarna ungu dominan (Anonim, 2013). Uji belah dilakukan dengan menghitung biji berwarna coklat penuh, sebagian coklat sebagian ungu, dan ungu penuh. Cara yang lain adalah dengan menggunakan alat pembelah biji kakao semi mekanis yang dapat membelah biji kakao dengan jumlah 50 biji sekaligus sehingga dapat diketahui persentasenya (Mulato, 2008). Metode uji belah dapat memberikan informasi tentang persentase tingkat fermentasi suatu sampel biji kakao yaitu slaty (0-20\%), ungu (20$40 \%)$, ungu dominan terhadap cokelat (40-60\%), cokelat dominan terhadap ungu (60-80\%), dan cokelat penuh (80-100\%) (Yusianto et al., 2008). Uji belah terlihat pada Gambar 2.

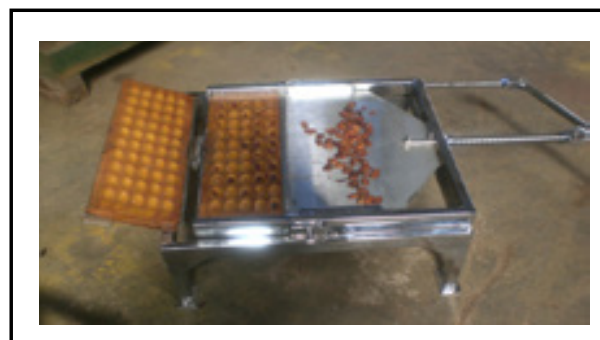

(a)

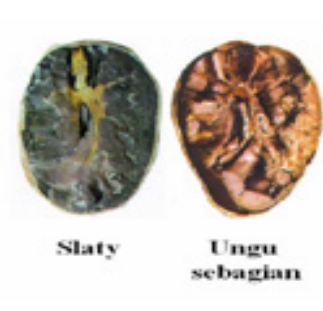

(b)

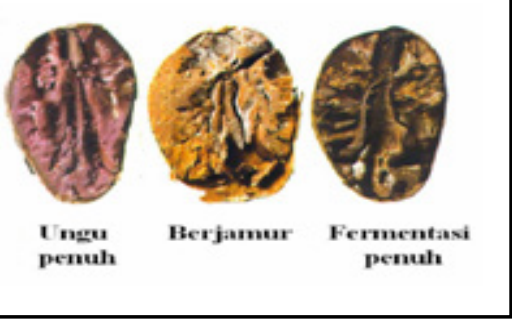

Gambar 2. (a) Alat Uji belah (b) Perubahan Warna Biji Kakao yang Difermentasi ('Nurhayati, 2010 ; bMulato, 2008)

Penelitian Rohan dalam Jinap et al. (2008) dan Caligiani dalam Jalil and Ismail (2008) mengklasifikasikan warna biji kakao menjadi tiga kelompok yakni warna slaty mengindikasikan biji kakao tidak terfermentasi (unfermented), ungu berarti biji kakao belum terfermentasi sempurna atau sebagian (underfermented), dan cokelat berarti biji kakao terfermentasi (fermented). Fermentasi dianggap sudah mencukupi bila $50 \%$ biji terdapat cairan ungu merah kecoklatan serta warna merah kecoklatan di sisi luar kotiledon. Fermentasi berakhir bila biji tampak kering (lembab), berwarna coklat, dan berbau asam (Anonim, 2013). 
Pengukuran indeks fermentasi juga dianggap masih kurang efektif dan efisien, memerlukan waktu yang lama dan biaya yang mahal, karena menggunakan bahan kimia. Uji belah masih dianggap kurang efektif dan efisien serta kurang akurat, karena cara ini membutuhkan ahli dalam penilaian warna biji kakao dengan standar sama dalam jumlah yang banyak secara cepat (Suharyanto dan Mulato, 2008). Metode uji belah bersifat subyektif karena berdasarkan pengamatan secara visual. Subyektivitas ini menyebabkan perbedaan pendapat antara pedagang dan petani tentang kualitas biji yang sedang diperjualbelikan. Umumnya petani merupakan pihak yang dirugikan karena posisi tawarnya yang rendah, sehingga pada akhirnya petani enggan melakukan fermentasi karena tidak adanya perbedaan harga yang memadai antara biji kakao fermentasi dan tidak difermentasi (Nurasa dan Muslim, 2009). Kelemahan uji belah yang lain adalah nilai pengukuran tidak mencerminkan kualitas produk cokelat yang dihasilkan dari biji kakao. Kesulitan penentuan akhir fermentasi dengan metode ini dikarenakan ketidakseragaman biji kakao yang terfermentasi, sehingga diperlukan metode yang efektif untuk menentukan akhir fermentasi (Anonim, 2013). Untuk menghindari permasalahan penentuan kesempurnaan tingkat fermentasi, perlu adanya inovasi berbasis teknologi digital sehingga dapat diketahui tingkat fermentasi secara obyektif, efektif dan efisien. Salah satu inovasi teknologi digital ini adalah penggunaan sensor warna untuk menentukan akhir fermentasi. Diharapkan alat tersebut dapat digunakan sebagai acuan jual beli yang obyektif sehingga biji kakao yang dihasilkan memenuhi standar SNI
2323-2008, mendapat harga yang tinggi dan mendorong petani kakao melakukan proses fermentasi dengan lebih baik.

\section{Teknologi Digital Sensor Warna}

Sensor warna merupakan sistem yang mempunyai kemampuan untuk mendeteksi warna, mengubah data analog menjadi digital, mengolah data digital, dan menampilkan hasil olahan. Warna yang dapat dilihat oleh manusia merupakan cahaya. Cahaya tampak mempunyai energi elektromagnetik dengan frekuensi $790-400$ $\mathrm{THz}$ dan panjang gelombang antara 400$700 \mathrm{~nm}$. Warna dasar penyusun atau warna primer terdiri dari warna merah, hijau, dan biru atau lebih dikenal dengan istilah RGB (red-green-blue). Sensor warna mengambil data suatu warna menggunakan kamera video, data ini merupakan data analog yang diubah menjadi data digital (Gunadhi, 2002).

Teknologi digital sensor warna untuk menentukan akhir fermentasi biji kakao telah dilakukan. Inovasi teknologi ini dibuat dengan memanfaatkan perubahan warna biji kakao pada proses fermentasi. Perubahan warnanya dideteksi, diproses, dan ditampilkan pada LCD dalam bentuk angkaangka yang menunjukkan akhir fermentasi. Penelitian Nurhayati (2010) mengukur tingkat fermentasi biji kakao dengan alat sensor warna hasil penelitian Suharyanto dan Mulato (2008), dimana diagram blok sistem secara keseluruhan alat sensor warna terlihat pada Gambar 3. Alat ukur indeks fermentasi ini menggunakan software yang dapat mengontrol kinerja mikrokontroler Atmega 8 AVR dan menampilkan angka hasil pengolahan mikrokontroler dengan metode spektrofotometer (Suharyanto dan Mulato, 2008). 


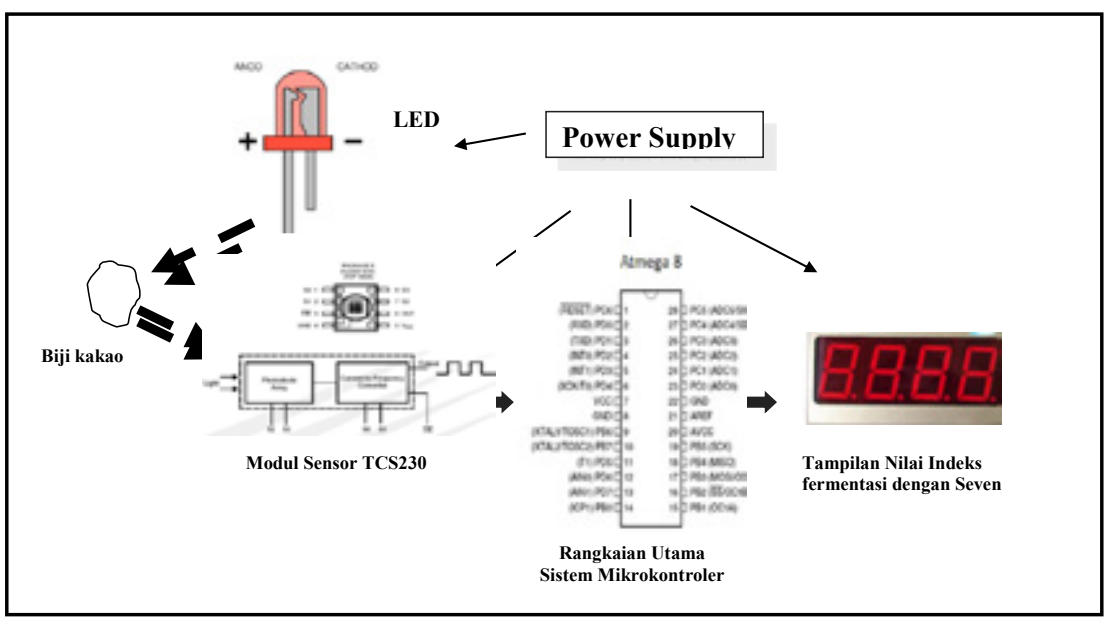

Gambar 3. Diagram Blok Sistem Keseluruhan Alat Sensor Warna (Suharyanto dan Mulato, 2008)

Secara umum komponen utama alat sensor warna ini adalah adaptor dan power supply, LED, modul sensor TCS230 yang terdiri dari photodioda dan pengkonversi arus ke frekuensi, mikrokontroler Atmega 8535L, display/7 segment. Mekanisme kerja alat tersebut dimana sampel biji kakao yang dibelah atau berbentuk pasta dimasukkan pada kuvet kemudian disinari dengan radiasi LED (Light Emitting Diode) berwarna clear. Sinar warna clear merupakan gabungan sinar dengan berbagai panjang gelombang. Sinar yang memiliki panjang gelombang yang sama dengan warna sampel kemudian dipantulkan menuju modul sensor warna, sedangkan sinar dengan panjang gelombang berbeda akan diserap oleh sampel. Sensor berbasis silikon photodioda menangkap warna pantulan, sensor ini akan mengubah intensitas cahaya menjadi pulsapulsa satuan frekuensi. Pulsa-pulsa ini ditangkap oleh mikrokontroler dan diproses menjadi satuan lama fermentasi (waktu) atau satuan indeks fermentasi (persentase). Kemudian mikrokontroler mengatur drive 7 segment untuk menampilkan nilai hasil olahan mikrokontroler. Alat sensor warna ini mampu mengukur tingkat fermentasi pada sampel seperti halnya spektrofotometer untuk semua klon dengan persentase error alat maksimal adalah 5,59\%.

Penelitian Ridho (2011), menggunakan mikrokontroler Atmega 16 dan sensor warna biji kakao TCS 230-DB yang mempunyai 4 buah mode filter warna yaitu mode filter merah, mode filter hijau, mode filter biru, dan mode filter clear (RGBC). Output berupa frekuensi untuk diolah di mikrokontroler Atmega 16. Hasil akhir berupa tampilan indeks fermentasi yang terlihat pada LCD 2X16 Display. Indeks fermentasi kemudian dikalibrasi dengan hasil indeks fermentasi spektofotometer. Hasil pengujian menunjukkan alat bekerja cukup baik dengan tingkat keberhasilan 89\%. Error persentase alat terbesar dalam pembacaan indeks fermentasi sebesar $10,90 \%$ dan terkecil 0,12\%.

Hasil penelitian menunjukkan bahwa alat sensor warna mampu mengukur tingkat fermentasi seperti halnya spektrofotometer. Pengukuran tingkat fermentasi biji kakao menggunakan teknologi digital sensor warna merupakan suatu inovasi teknologi yang dapat digunakan untuk keperluan transaksi jual beli. Diharapkan dengan adanya inovasi ini, biji kakao yang dihasilkan merupakan biji kakao yang sudah terfermentasi sempurna. Teknologi ini cukup efektif dan efisien karena mampu mempersingkat waktu pengujian serta menghindari penggunaan bahan kimia dan penilaian subyektif.

\section{KESIMPULAN}

Aspek mutu dalam SNI biji kakao yang sangat penting adalah tingkat fermentasi 
yang sempurna. Fermentasi sempurna umumnya diketahui dengan metode uji belah (uji belah). Cara uji subyektif ini dapat menimbulkan perbedaan persepsi antara pedagang dan petani tentang kualitas biji kakao hasil fermentasi. Inovasi teknologi berbasis teknologi digital perlu dilakukan untuk mengetahui tingkat fermentasi secara obyektif, efektif dan efisien. Salah satunya adalah menggunakan sensor warna yang mampu mempersingkat waktu pengujian serta menghindari penggunaan bahan kimia dan penilaian yang subyektif. Alat ini diharapkan digunakan sebagai alat proses kontrol selama biji kakao difermentasi agar diperoleh biji kakao dengan mutu terfermentasi sempurna.

\section{DAFTAR PUSTAKA}

1. Afoakwa, E.O., Paterson, A., Fowler, M and Ryan, A., 2008. Flavor formation and character in cocoa and chocolate. Critical Review in Food Science and Nutrition. Taylor and Francis Group. United kingdom.

2. Anonim. 2013. Pasca Panen, Kualitas Biji Kakao dan Fermentasi. Swisscontact. Medan.

3. Beckett, S. T. 2009. Industrial Chocolate Manufacture and Use. $4^{\text {th }}$ edition. Blackwell Publishing, York, Inggris.

4. Camu, N., Winter, T.D., Addo, S.K., Takrama, J.S., Bernaert, H and Vuyst, L.C., 2008., Fermentation of cocoa beans: influence of microbial activities and polyphenol concentration on the flavour of chocolate. Journal Science Food and Agriculture. 00225142. Society of Chemical Industry. Belgium. $2288-2297 \mathrm{~h}$.

5. Ditjenbun, 2011. Renstra Direktorat Jenderal Perkebunan 2010-2014. Direktorat Jenderal Perkebunan. Kementerian Pertanian. Jakarta.

6. Ditjenbun, 2016. Statistika Perkebunan Indonesia 2015-2017. Kakao. Direktorat Jenderal Perkebunan. Kementerian Pertanian. Jakarta.
7. Elisabeth, D.A.A. dan Rubiyo.,2006. Pengaruh Lama Fermentasi terhadap Mutu Kimia Bubuk Cokelat. Warta Penelitian dan Pengembangan Pertanian, Vol. 22 No. 2, 2006. BPTP. Bali. 82-90 h.

8. Galvez, S.L.,, Loiseau, G., Paredes, J.L., Barel, $M$ and Guiraud, J.P., 2007. Study on the microflora and biochemistry of cocoa fermentation in the Dominican Republic. International Journal of Food Microbiology. 114 (2007) 124-130. Republik Dominika.

9. Gunadhi, A, 2002. Sensor Warna dengan Menggunakan Kamera Video Berbasis Komputer Pribadi. Proceeding Komputer dan Sistem Intelijen. Universitas Mandala Surabaya. Surabaya.

10. Hansen., C.E., del Olmo., Burri, $C$ and Burri, C.,1998. Enzyme activities in cocoa beans during fermentation. Journal of The Science of Food Agriculture. Vol 77 Issue 2. $273-281 \mathrm{~h}$.

11. Haryadi dan Supriyanto., 1991. Pengolahan Kakao menjadi Bahan Makanan. PAU Pangan dan Gizi Universitas Gadjah Mada. Yogyakarta.

12. ICCO, 2018. ICCO Quarterly Bulletin of Cocoa Statistics. Vol XLIV, No. 2, Cocoa Year 2017/2018. Published: 31 Mei 2018.

13. Jalil, A.M.M and Ismail A., 2008. Polyphenols in cocoa and cocoa products : is there a link between antioxidant properties and health. Review Molecules 13 DOI; 10.3390,. University Putra Malaysia. Malaysia. $2190-2219 \mathrm{~h}$

14. Jinap, S., Ikrawan, Y., Bakar, J., Saari, $S$ and Lioe, H.N., 2008. Aroma prekursor and methylpyrazines in underfermented cocoa beans induced by endogenous carboxypeptidase. Journal of Food Science. Vol 73 Nr.7. Institute of Food Technologists. Malaysia. 141 - 147h.

15. Kholis, D, 2009. Produksi kakao Standar Ekspor. Direktorat Jenderal Industri 
Kecil dan Menengah. [serial online]. Departemen Perindustrian. Jakarta.

16. Langsa, Y. 2008. Upaya peningkatan produksi dan mutu hasil kakao melalui penggunaan klon unggul baru.Disampaikan pada Prosiding Seminar Nasional Pengembangan Inovasi Pertanian Lahan Marginal. Balai Pengkajian Teknologi Pertanian Sulawesi Tengah. Sulawesi Tengah.

17. Misnawi, 2005. Peranan Pengolahan Terhadap Pembentukan Cita rasa Cokelat. Warta Pusat Penelitian Kopi dan Kakao. Vol. 21 (3). Oktober 2005, Jember.

18. Mulato, 2008. Pengolahan Kopi dan Kakao. Handout Materi Kuliah Program Pasca Sarjana Universitas Jember. Jember

19. Mulato, S., S. Widyotomo, and Suharyanto., 2008. Cocoa Processing Technology Development an Integrated Approach. Agro Inovasi.Jember

20. Nurasa, T, Muslim, C., 2009. Perkembangan kakao indonesia dan dampak penerapan kebijakan eskalasi tarif dipasaran dunia: kasus kabupaten kolaka, provinsi sulawesi selatan. Pusat Analisis Sosial Ekonomi dan Kebijakan Pertanian Bogor. Badan Litbang Pertanian, Bogor

21. Nurhayati. 2010. Pengukuran Tingkat Fermentasi Beberapa klon kakao Lindak dengan Teknologi Digital Sensor warna. Program swdi Agronomi. Program Magister Jurusan Budi daya Pertanian. Fakultas Pertanian Universitas jember

22. Purba F. HK. 2009 Upaya Ekspansi Pasar Kakao Indonesia ke Eropa (serial online) Direktorat Pemasaran Internasional Ditjen PPHP Jakarta.

23. Ridho, A.H, 2011. Penentu Tingkat Fermentasi Biji Kakao Menggunakan Sensor Warna Dengan Mikrokontroler Atmega 16. Program Studi Diploma III Teknik Elektronika. Jurusan Teknik Elektro. Fakultas Teknik. Universitas Jember.
24. SNI 01-2323-2008. Biji kakao. ICS 67.140.30. Badan Standardisasi Nasional.

25. Suharyanto, E., dan S. Mulato. 2008. Kinerja Perangkat Elektronik Digital untuk Mengukur Lama Fermentasi Biji Kakao (Theobroma cacao L.). Disampaikan pada Simposium Kakao 2008, 28 - 29 Oktober 2008 di Denpasar Bali. Pusat Penelitian Kopi dan Kakao Indonesia. Jember.

26. Sulistyowati, 1988. Keasaman biji kakao dan masalahnya. Pelita Perkebunan Vol 3 No 4 Pusat Penelitian Kopi dan Kakao Indonesia. Assosiasi Peneliti Perkebunan Indonesia. 151-158h.

27. Thompson,S.S., Miller,K.B and Lopez,A.S., 2001. Food Microbiology Cocoa and Coffee. ASM Press. Washington, D.C. 721-733 h.

28. Wahyudi, T dan Misnawi., 2007. Fasilitas perbaikan mutu dan produktivitas kakao Indonesia. Warta Penelitian dan Pengembangan Pertanian, Vol. 26 No. 1, 2007.

29. Yusianto, Wahyudi, T., dan Winarno. 1997. Mutu dan pola cita rasa biji beberapa klon kakao lindak. Pelita Perkebunan Vol.13 No 3 September 1997. Pusat Penelitian Kopi dan Kakao Indonesia. Assosiasi Peneliti Perkebunan Indonesia.

30. Yusianto, Wahyudi,T dan Sulistyowati. 2008. Bab 15 Pasca Panen, dalam Wahyudi, T., R Panggabean dan Pujiyanto (Ed).Panduan Lengkap Kakao Managemen Agribisnis dari Hulu Hingga Hilir. Penebar Swadaya. Jakarta. 207 h. 